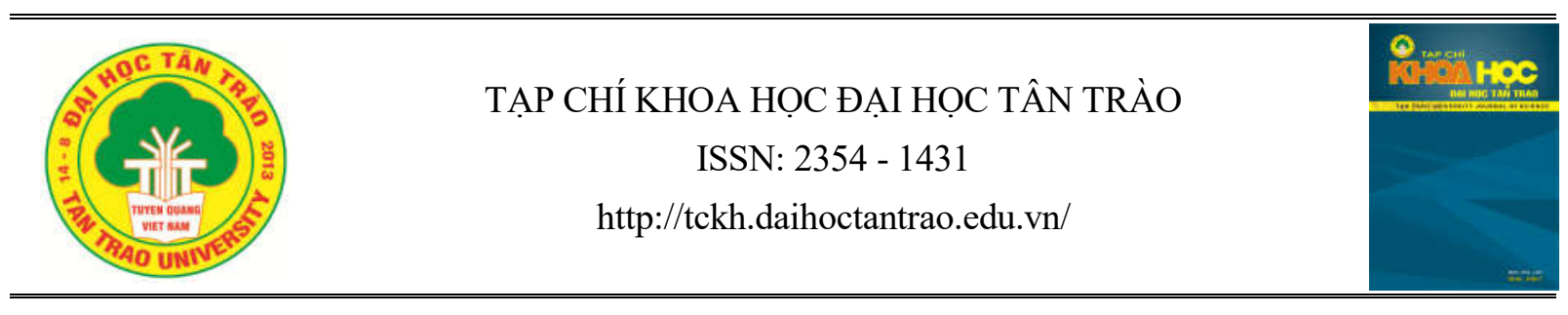

\title{
Lao culture in the novel "Plains of jars" by Trinh Thanh Phong
}

\author{
Tran Thi Le Thanh ${ }^{a^{*}}$ \\ ${ }^{a}$ Tan Trao University \\ *Email:lethanhcdtq@gmail.com
}

\section{Article info}

Recieved:

09/11//2018

Accepted:

$10 / 12 / 2018$

Keywords:

Trinh Thanh Phong's

novel; Chum field land;

Lao cultural imprint

\begin{abstract}
Trinh Thanh Phong is one of the typical writers of prose in Tuyen Quang. At the age of sixty five, he has not only contributed much good writing such as novels, poems and stories, for Tuyen Quang literature in particular and Vietnamese literature in general, but also has won awards abroad. "Land at Plains of Jars" is a novel which got Dong Duong Award in the Mekong River Literature Prizes. These were the friendship prizes among Vietnam, Laos and Cambodia awarded in Phnom Penh city in 2008. This paper addresses issues concerning the cachet of Laos culture (especially in friendship between Laos and Vietnam), base on the novel "Plains of Jars"..
\end{abstract}

\section{Trinh Thanh Phong - Life and Career}

\subsection{About his life}

Trinh Thanh Phong (Penname: Hai Thanh) was born on February $20^{\text {th }}, 1950$ in Phu Chinh Village, Vinh Tuong, Lap Thanh, Vinh Phuc, however, he was grown up in Thong Village, Lam Xuyen Commune, Son Duong District, Tuyen Quang.

Until now, there is no document to show about his family class. Many people base on his works to have their own assessments. The question about his family position and class still remained unanswered if the works named "Ngay tho dai" (Childhood Days) was not created. In his works, writer Trinh Thanh Phong opened every pages of his life to the readers. Through the pages of this works, he described about the hard days when he spent his childhood with rivers, rice fields, with buffalo and the plow, with hard days and familiar village customs. The story he told about his grandmother was so touched which helped the readers to understand deeply his family position and class: "My grandma was born in Phu Vinh Tuong. Her father was a teacher and her mother was a farmer. When she was a girl, she followed other farmers to this place ....she went to seek for shelter"[1]. He was proud of his grandma as he was proud of his hometown. He was grown up and lived with that pride because he was deeply aware that "the secrets from blends in the clothes as well as the saltiness in the tears from my grandma's eyes dropping into the rice fields in the early morning that day!....

Then, it was also so honorable to him for the days he was trying very hard for his career. When he was at high school, the boy of 18 years old was excited to join the army. In the first days, Trinh Thanh Phong was at the battlefield in Laos. This was the time for the writer to accumulate the practical experience about the soldiers and the daily life. Especially, he had the opportunity to approach the culture (Lao Culture) which was of long tradition and quite developed in his opinion. In difficult living conditions at the battlefield with his fellow comrades who faced the death everyday, Trinh Thanh Phong deeply felt and understood the camaraderie with his Lao friends. Suffering from losses, sacrifices, the extraordinary efforts paid by him and his Lao friends became the valuable capital for the writer to shown in his works later.

After Paris Agreement was signed (1973), the writer Trinh Thanh Phong could continue his high school 
education at Military Culture School (Lang Son) which was later upgraded in Logistics Institute. At the end of 1976, because of his poor health conditions and "karma" (as he said), he applied for discharging from military service to work at Department of Culture and Information of Ha Tuyen.

From 1998 until 2008, writer Trinh Thanh Phong was nominated to hold the position of chairman Literature and Art Association in Tuyen Quang cum Editor-in-Chief of Tan Trao Newspaper. Now, he was retired and still continues writing the pages full with humanistic spirit.

\subsection{Career}

Writer Trinh Thanh Phong has many works printed on the central and local newspapers since 1980s, however, until 1990s, these works were officially published and introduced to the readers with the first short stories in the collection of short stories named $\mathrm{Bai}$ Cuoi Song (The alluvial Plain at the end of River). Since then, he has published more than ten books with hundreds of works: Gap Lai (See Again) (Collection of Short Stories. Cultural and National Publishing House, 1998); Doi Mat Vang Trang (The Eyes and the Moon) (Collection of Poems - Association of Letters and Arts of Tuyen Quang, 1999); Loi Ru Ban Mai (Morning Lullabies) (Collection of Short Stories - Cultural and National Publishing House, 2000); Ma Lang (Village Ghost) (Novel - Writers Association Publishing House, 2002); Buc Tuong Xanh (Green Wall) (Collection of Stories - Kim Dong Publishing House, 2003); Duoi Chan Nui Bac Quan (Under Bac Quang Mountain Foot) (Collection, Cultural and National Publishing House, 2006); Dong Lang Dom Dom (Village Field and Firefly) (Novel, Literature Publishing House, 2010); Hien $\mathrm{Ra} \mathrm{Tu}$ Huyen Thoai (Born from the Legend) (Collection, Cultural and National Publishing House, 2010); Dat Canh Dong Chum (Plains of Jars) (Novel, Writers Association Publishing House, 2007); Ong Manh Ve Lang (Deceased bachelor comes back village) (Novel, Literature Publishing House, 2009); Mien Sang (Collection of Short Stories, People's Army Publishing House, 2015); Trinh Thanh Phong Novel (Writers Association Publishing House, 2014); Ngay Tho Dai (Days of Childhood) (Long storey, Kim Dong Publishing House, 2014).

In addition, he also has many works printed on Tan Trao Newspaper, Van Nghe Newspaper, People's Army Magazine etc. since 1970 to date and some works selected to post in Tuyen Quang Poems and Literature 1999-2004 and Collection of 20 years of Tuyen Quang Literature, collections of selected short stories of Vietnam Writers' Association etc...

\section{Beauty of Lao Culture}

\subsection{Summary on Laos}

In terms of population, Laos is a thinly-populated country (the population of more than 6 million people/236,800 $\mathrm{km} 2$ ). The population is stretching throughout the country through different geographical locations with many typical cultural features. Laos has more than 60 ethnic groups in which the majority is from three main ethnic groups of Lao Lum (belonging to Lao-Thai language group with the population of about 2 million people, accounting for 70\% of Laos's population) who are mainly living in low areas mainly including valleys and river deltas along rivers; Lao Thong people (belonging to Mon-Khowme language group) mainly live in the midlands. Compared to other groups, this is the local population group living for longest time in Laos; Lao Xung people (belonging to Han Tang language group) mainly live in temperate highland in the North and Central Laos. This group of people mainly lives on the nature with simple farming techniques, therefore, the economic conditions are generally lower than other groups.

In terms of history, since XIV ${ }^{\text {th }}$ Century, Laos had recorded their official history when the feudal state with centralized power was formed by King Fa Ngum in 1353. Basing on the archaeological evidences, Lao society in the pre-history period was developed from clans, tribes to the primitive communalism respecting to the development from Paleolithic, Neolithic, Bronze to Iron Age.

Since $\mathrm{XIV}^{\text {th }}$ Century to $\mathrm{XIX}^{\text {th }}$ Century, Lao feudalism had developed through many dynasties such as King Fa Ngum, King Setthathilat; King Xulinha Vongxa etc. In 1893, French Colonialism agreed and cut the right bank of Mekong River for Siam to govern and the left bank of Mekong River belonged to the French Colonialism. In 1930, the The Communist Party of Indochina (former name of The Lao People's Revolutionary Party) was formed to lead the people of Laos to fight against the French Colonialism. In 1945, Laos declared the independence on October $12^{\text {th }}$. Same as Vietnam, the peace did not last long, the American Empire invaded Laos. And in 1955, The Lao People's Revolutionary Party was formed to directly lead the 
resistance war against the United States. With the supports from other countries in the world, especially Vietnam, on December 2nd, 1975, Lao Revolution won completely and the Lao people has enjoyed the peace until now.

In terms of organizational structure, Laos society was formed early with village unions (Xieng in Lao language) and then developed into ancient towns. Ancient towns had existed to form and develop the tradition and cultural identity of Laos. Many intangible and tangible cultural heritages of Laos are still preserved to witness the cultural life of Lao people in these ancient towns. It is a pity that Laos was annexed by Siam in the XVII ${ }^{\text {th }}$ Century which destroyed seriously Lao culture.

\subsection{The beauty of Lao Culture}

Similar to many other neighboring countries in Southeast Asia (especially Vietnam), Laos is a country with long-aged and quite developed culture. As a flow of fresh water continuously from this generation to another generation, Lao culture has created the soul, spirit and traits of Lao identity. Through the periods of history, Lao culture has been existed together with the diversified customs, habits, religions, and beliefs.

The first beauty in Lao culture should be customs and habits closely linked to the unique traditional festivals. Well-known as the country with festivals all year round, Laos celebrates its traditional festivals in very special and different way of Lao people. As almost other countries in Southeast Asia, Lao festivals includes main New Year festivals (Solar New Year, Lunar New Year (as in some other Asian countries), Lao New Year (Bun PiMay in April) and H'mong New Year (in December) and many other festivals in the whole year such as Bun Phavet (Buddha reincarnation) in January; Bun VisakhaPuya (Vesak) in April; Bun BangPhay (squib) in May; Bun Khao PhanSa (Lent) in July; Bun Khao Padapdin (in memory of the deceased) in September; Bun Suanghua (boat race) in October etc.

Only basing on the names and spirits of the Festivals in Laos, it can be seen that in terms of culture, Laos is a Buddhist country. Buddhist was passed into Laos since $7^{\text {th }}$ Century and has become the state religion since $14^{\text {th }}$ century. With the population of more than 6 million people, there are more than 5 million people (accounting for more than $90 \%$ of population) have special respects to the Buddha, Buddhist scriptures and monks in the temples. Therefore, Laos built 1,400 big and small pagodas with the typical cultural, historical and architecture values to become the places for worshiping the Buddha and the places where the tourists can visit. Many cultural activities of Lao people have deep imprints of Buddhist culture. Temples are closely linked to schools, the life of Buddhists at home. Especially, since the Buddha is the state religion, Laos people consider that ethnical standards in the Buddhist scriptures as the ethnical standards that the whole society should follow. It is easy to find out that Lao people are often compassionate, gentle and willing to share and support each other.

In addition to religion, belief and traditional festivals, it often talks about the symbol of the country and people of Laos - that is the symbol of Champa flower. This symbol shows and reflects clearly the national culture, identity and soul of Lao people. That is a peaceful country with the quiet, gentle and simple people who are willing to sacrifice for their nation.

Finally, when talking about the beauty that creates the culture of the Land of a Million Elephants, the country of Champa flower, it should mention about the interesting and amazing natural landscapes and relics such as That Luong (Vientiane), Luang Prabang ancient town (the world cultural heritage), Vatxixun temple, $\mathrm{Phu} \mathrm{Xi}$ mountain, mysterious plains of jars (Xiengkhuang), Khone Falls, Kuang Si Falls, Tham Ting cave etc. which all together create the imprint of Buddhist culture which cannot be mixed with any other countries in Southeast Asia.

Talking about the mysterious beauty of Plains of jars, it is the well-known place that everyone who once visits the land of a Million Elephants should not forget. For Vietnamese people, the name of Plains of Jars is very familiar too. The legends about Plains of Jars had followed the Vietnamese soldiers when they were in Laos. However, we can only feel fully its beauty and the cultural values hidden in these valuable cultural heritages when we can see the plains with our own eyes and touch the stone jars with our own hands and listen to the legends about the formation of stone jars. Plains of Jars has become the cultural and historical address and a famous tourism destination throughout the world of this Land of A Million Elephants.

\subsection{Vietnam-Laos Friendship}

Vietnam and Laos are two neighboring countries with the close relationship which has been formed and strengthened through thousands of years of country 
construction and keeping. The beautiful relationship between two nations have been built and strengthened by President Ho Chi Minh and President Kaysone

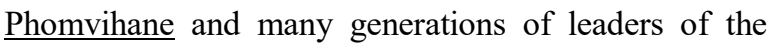
parties and people of two countries. Looking back the history, we are so proud of the special and valuable relationship between two nations. In the war against the old colonialism, two countries formed Vietnam-Laos troops to together fight against our shared enemy. The first Vietnamese voluntary soldiers came to Laos to together with Pathet Lao soldiers to protect the beautiful country of Laos. The close cooperation of two nations, the determination and sacrifice for the beautiful friendship had resulted in the glorious victory for two countries in the resistance war with the signing of Genève 1954 Agreement on Indochina.

In the war against the neocolonialism - American Empire, the solidarity between Vietnam and Laos had become even deeper. On September 5th, 1962, Vietnam and Laos officially established the diplomatic relationship to open a new phase in the history of two countries. The union troops of two countries of Vietnam and Laos defeated many wicked conspiracies of the enemy. The relationship between the people in Vietnam-Laos border has been strengthened. The mighty Truong Son Mountain Range with two halves of Eastern Truong Son and Western Truong Son had become the dynamic image for that relationship. The solidarity of Vietnamese and Lao people in the hard but glorious years had contributed considerably to help the people and armed forced of two countries to go from this victory to anther victory. Spring 1975 Great Victory in Vietnam and Victory on December 2nd 1975 in Laos was the result of extraordinary efforts and revolutionary achievements of two nations.

\section{Novel Plains of Jars from cultural view}

Trinh Thanh Phong is the author of the Novel Plains of Jars which helps him to become the owner of Indochina Prize - Mekong River Literature Prize about the friendship between three countries of Vietnam, Laos, Cambodia in 2008. This novel shows deeply the cultural beauty and spiritual life of the soldiers in the friendship relationship of Vietnam-Laos in the war. As said by Author Nguyen Van Thuyet: "the author awarded with Mekong Literature Prize (Cambodia, Laos, Vietnam) is really worthy for his talent, battlefield experience of the writer himself and the sacrifice of this comrades [3 - page 126].
The novel does not focus on building an ideal example, a typical characteristics or a story core with many complicated and sudden situations around the main character etc. it tells about the Vietnamese soldiers in the relationship with Lao soldiers, Lao people in the hard days of the war on the Plains of Jars in Xiengkhuang province. Through the pieces of the war, the beauty of the soul and portraits of Lao soldiers and people are clearly presented in every single page.

Once joining the voluntary troops in Laos, and experiencing the hard days of the war, more than anyone else, Trinh Thanh Phong fully and deeply felt and understood the characteristics of Lao people and the beauty of their souls. In communication, Lao people are very sentiment and hospitable. For every relationship, Lao people are very close, sincere and tolerate. In the life, Lao people are very gentle, honest and simple. In job, Lao people attach much importance on honor. Worshipping the Buddha and being influenced by the moral thought of Buddhism, Lao people are willing to help the people in need and difficult situations etc. In addition to the twinning procedures, Lao people consider those who spend hard times with them as brothers and sisters. In Plains of Jars, writer Trinh Thanh Phong spent many pages to describe these characteristics of Lao people. The uprightness, honesty and extremely tolerance of Pho Dum were described by the writer with the beauty of appearance and the soul. The way of thinking of Pho Dum about the war was very simple but he inevitably believed in the final victory: "Village is too simple! All beautiful houses were destroyed by the enemy. But bombs of the enemy could only collapse the houses but land. We have land, we have everything!. The enemy gone, we will build beautiful and big houses". The feeling of Pho Dum to Lao soldiers, Vietnamese soldiers and Lao people are also very deep: "You have gone for a week, Pho comes this tunnel every afternoon to tidy up and looks at the cloud on Phu Nhu mountain and feels so anxious. Pho can be only happy when you are all at home" "[2 - page 43]. Pho Dum's expectation and wish about the war are really respectable: "We have to fight a big battle to liberate Laos, Bua Van will hide the big gun into the mountain and bring books and pens to the children in Na Khum to go to school to learn. The people in $\mathrm{Na}$ Khum hamlet will plant rice, maize and build beautiful and big houses. At night, Lam Vong will be extended to Khang Khay Street. Girls and boys in the hamlet will sing and dance with Vietnamese 
soldiers. It must be so cheerful to drink wine with Vietnamese soldiers. Pho Dum's face is brightened with hopes"[2 - page 44]. The pure and extremely exquisite beauty of Bua Van, Bua Khan and the solid faith and will of Thao Sun, Kham Din etc. were also shown convincingly by writer Trinh Thanh Phong. The way of thinking of Can in Plains of Jars is also the way of thinking of many Vietnamese people when living together with Lao people: " Lao people are supported with the back as firm as copper wall because of people like Pho Dum, Bua Van, Bua Khan, Thao Sun, Kham Din etc. with the faithfulness to the resistance war. This lights up the trust that "The American people cannot be the winner of this war regardless of modern weapons and elite troops that they have [2 - page 46]. The pride of Can and the confidence full with sincere affection from the heart with Lao people were also shown in moved way through this words to his mother "I am under the ground at Phu He Mountain. The ground here is very warm and solid. The ground is as the souls of Lao mothers! Lao people and Lao country are wholehearted to protect us just like you. I am very happy because Bua Van tied a red thread into my hand! Mom, that red thread has much special meaning. The Buddha is in this thread to tie this fate between me and Bua Van! [2 - page 56].

Having its own traditional cultural characteristics, Vietnamese and Lao people have many things in common because of originated from the agricultural culture. "Through every pages of Plains of Jars, we can see the names, and lives of Vietnamese people and Lao people alternatively who shared the same fighting trench, were at the same battlefield for the shared determination of defeating the enemy" [4 - page 126] .

In addition to giving the good impression about the beautiful friendship and the beauty of Lao people, Plains of Jars is also deeply influenced by the Lao culture, culture of Plains of Jars with the special and unique customs, by the names of locations, villages which are closely linked to the memory about the war time. The image of Pho Dum who passed the empty bowls of wine and the melody of "in every singing words, there are the perfume and beauty that are crystallized from the mountains, from the forest of this mysterious and simple land - Land of a Million Elephants! The singing voice and the twinkle hands under the moonlight which is full in the eyes to lift up the moon to fly with the dews following the dancing and following the dancing hands" [2 -page 52] will be deeply in the hearts of two countries of Vietnam and Laos forever.

\section{REFERENCES}

1. Trinh Thanh Phong (2014), Childhood Days, Long story, Kim Dong Publishing House.

2. Trinh Thanh Phong (2007), Plains of Jars, Novel, Writers Association Publishing House.

3. Nguyen Van Thuyet (2009), Reading Novel Plains of Jars by Trinh Thanh Phong, some feelings, Tan Trao Newspaper, Edition No. $49-1^{\text {st }}$ Period in May 2009.

4. Tran Huy Van (2013), Plains of Jars - The love song about Vietnam-Laos Battle, Tuyen Quang Literature in Innovation Period (1986 - 2006) - Works and Comments, Thai Nguyen University Publishing House. 


\section{Dấu ấn văn hóa Lào trong tiểu thuyết "Đất cánh đồng chum" của Trịnh Thanh Phong}

Trần Thi Lệ Thanh

\section{Thông tin bài viết}

Ngày nhận bài:

09/11//2018

Ngày duyệt đăng:

10/12/2018

\section{Tù khoá:}

Tiểu thuyết Trịnh Thanh Phong; Đất cánh đồng Chum; Dấu ấn văn hóa Lào.

\section{Tóm tắt}

Nhà văn Trịnh Thanh Phong là một trong những cây bút tiêu biểu của nền văn xuôi Tuyên Quang thời kỳ Đổi mới. Ông thuộc thế hệ nhà văn trưởng thành sau 1980 và đặc biệt có nhiều thành tựu vào những năm đầu của thế kỷ XXI. Với 65 năm tuổi đời và ngót 40 năm cầm bút, ông không chỉ đóng góp cho nền văn học Tuyên Quang nói riêng, văn học Việt Nam nói chung về số lượng các tác phẩm (bao gồm đủ các thể loại tiểu thuyết, truyện ngắn, bút ký, thơ...) mà còn đóng góp nhiều tác phẩm có chất lượng, được ghi nhận bởi nhiều giải thưởng lớn trong và ngoài nước. Đất cánh đồng chum là cuốn tiểu thuyết đã nhận được giải thưởng Đông Dương - Giải thưởng văn học Sông Mêkông. Đây là giải thưởng về tình hữu nghị ba nước Việt Nam, Lào, Campuchia tại PhNôm Pênh năm 2008. Bài viết, trên cơ sở khái quát một vài nét về cuộc đời, văn nghiệp của Trịnh Thanh Phong và nét đẹp của văn hóa Lào, từ đó chỉ ra những nét văn hóa Lào đặc sắc trong tiểu thuyết Đất cánh đồng Chum. 